${ }^{1}$ L.N. Gumilyov Eurasian National University, Nur-Sultan, Kazakhstan;

${ }^{2}$ Abai Kazakh National Pedagogical University, Almaty, Kazakhstan

(E-mail: kazizat@mail.ru,mbsha1@mail.ru,berdyshev@mail.ru,asel.kembay@mail.ru,tokseit1990@gmail.com)

\title{
Mathematical modeling of the source and environment response for the equation of geoelectrics
}

\begin{abstract}
In this paper an algorithm is proposed for determining the source of excitation of electromagnetic waves emitted by the Ground-penetrating radar (GPR) device as a function of time. A mathematical model for solving this problem was constructed and tested on model data. We have built an algorithm for constructing a source function based on real georadar data. For this purpose, the results of experimental studies conducted in field conditions using the Loza-V GPR. Experiments were carried out in the medium: air-sand. The received signal of the response of the medium was processed from interference and noise. For this purpose, we use frequency filtering, signal averaging, amplitude correction for processing radarograms. In the future, the obtained table form of the disturbance signal will be used by us to study inhomogeneous media, including the study of localized objects. The series of calculations for the considered problems are given.
\end{abstract}

Keywords: inverse problems, source modeling, Maxwell equation, frequency filtering, radarogram processing, numerical results.

\section{Method for solving inverse coefficient problems}

The result of the GPR survey is a set of single traces (signals) recorded by the receiving antenna at each position of the GPR. To solve engineering problems, it is necessary to have the amplitude of the signal depending on the depth of its reflection, while the original radarogram is the dependence of the signal amplitude on the reflection time.

As you know, all radars can only record the time of reflection from the boundaries of objects or inhomogeneous media. On the other hand, it is a function of time or otherwise referred to as additional information (the response of the environment). This function is additional information for solving inverse problems, in our case determining the geological section. We present below the research methodology, which is one of the well-known methods for solving such problems.

The optimization method for solving inverse problems of electrical exploration is one of the most effective and widely used methods in practice.

The main ideas of the method were proposed by A.N. Tikhonov, M.M. Lavrentiev, V.K. Ivanov, G.I. Marchuk, A.S. Alekseev and many of their students and followers.

A. Bamberger, G. Ghavent, P. Lailly [1] used and investigated the conjugate gradient method to solve the one-dimensional inverse seismic problem. The essence of the method is to minimize the quadratic function of the discrepancy of observed and calculated fields. The application of the method to field data is given in the articles of A. Bamberger, G. Chavent, Ch. Hemon, and P. Lailly [2]. The method of least squares was also used to reverse the data obtained during the registration of seismic fields, see D.A. Cook, W.A. Schneider [3], and W.W. Johonson, H.H. Nogami [4].

In the article of G. Chavent, M. Dupuy, P. Lemonnier [5] the optimization method was applied to the problem of determining the distribution of magnetic permeability.

In the article by F. Santosa, W. Symes, G. Raggio [6] considered the problem of determining the acoustic impedance of a layered medium from reflected seismograms in which low-frequency components are small or are absent.

A wide range of inverse problems of geoelectric and numerical methods for solving these problems (including the optimization method) are presented in the monograph of V.G. Romanov, S.I. Kabanikhin [7]. 
For the numerical solution of inverse problems of geoelectric in layered and vertically inhomogeneous media, the method of conjugate gradients is applied in the article of K.T. Iskakov, S.I. Kabanikhin [8].

The series of articles [9-12] is devoted to experimental and numerical studies of solutions of the direct and inverse problem of non-linear diffusion associated with the process of drying of porous materials. The experiments were conducted by a team of authors in the laboratory of magnetic and spin phenomena of the International tomographic center SB RAS and the Institute of Catalysis SB RAS. The results of experimental and numerical studies are published in $[9,10]$ and problem statements and the development of algorithms in [11, 12].

The complex includes an algorithm for calculating the concentration (direct problem) in the processes of drying (adsorption) of various porous materials (aluminium oxide, silica gel) containing liquid (water, acetone, etc.), adsorption of water vapor by selective water sorbents (silica gel or aluminium oxide, containing calcium chloride).

The results of numerical calculations of the solutions of the direct and inverse problems are in satisfactory agreement with the measurement data obtained experimentally.

The questions of the conditional stability of the inverse problem for the hyperbolic equation with Lipschitz constant depending on the depth, on the priori given norm of the unknown coefficient and the norm of the data of the inverse problem in space $H_{1}$ are reflected in [13].

The Fourier collocation method for reconstruction of the source function $\mathrm{F}(\mathrm{x})$ depending on the spatial variable is developed and tested on model examples. The inverse problem of source identification depending on the spatial variable $\mathrm{F}(\mathrm{x})$ in the one-dimensional wave equation is considered. The connection between this problem and the problem of georadar data interpretation (GPR) is shown [14, 15]. Articles [16, 17] are devoted to visualization of the obtained data for subsequent interpretation and obtaining reliable information about underground geological environments, natural and artificial inhomo-geneities, anomalies, objects. Visualization of the processed data of GPR and the description of the program of processing of signals of GPR for interpretation of subsurface geological environments are given.

In $[18,19]$ an effective algorithm (layer-by-layer conversion method) for solving the inverse problem for the geoelectric equation in the frequency domain for the simultaneous determination of the dielectric permittivity and medium conductivity, as well as determining the boundaries of discontinuity is presented.

The differentiability of the discrepancy functional is shown with allowance for media interface boundaries. With this in mind, the well-known algorithm for layer-by-layer conversion is generalized. Based on the critical frequency, a range is set for which two functions can be defined simultaneously.

In [20] the questions of conditional stability, the solution of the inverse coefficient problem for the equation of geoelectrics are studied. To study stability, the initial inverse problem is reduced to a system of the second kind of Volterra integral equations. The class of correctness of solutions of the inverse problem and the class of input data is introduced. The estimation of the conditional stability of the solution of the inverse problem from the input data in the normal space $H_{1}$ is obtained.

In [21], the residual functional for the numerical solution of the inverse problem for the equations of the theory of elasticity was investigated. The medium model is horizontally layered. The differentiability of the function of the discrepancy by the coordinate of the point of discontinuity of the medium for the equations of the theory of elasticity is proved. An explicit analytical expression for this derivative is obtained. This allows the gradient method to determine the coordinates of the gaps and the thickness of the layers.

Methods of estimation of various parameters of geophysical models were considered by D.W. Marquardt [22], Y.M. Chen, J.H. Seinfeld [23], G. Stoyan [24] and many others. Therefore, we note the review article of B. Ursin, K.A. Berteussen [25] and the bibliography available in it.

\section{Modeling the source of disturbances}

At a georadar research the device registers the signals received by the receiving antenna as a set of single routes in the form of the image - radarogramma [26, 27]. To solve engineering problems, it is necessary to have the dependence of the signal amplitude on the depth of its reflection, and the original radarogram is the dependence of the signal amplitude on the travel time. On an other hand, it is necessary to clear the signal from various kinds of noise that hides the useful signal. For this purpose, we use frequency filtering, signal averaging, amplitude correction [17] to process radarograms.

To solve the inverse problem of GPR, it is necessary to know the time dependence of the signal entering the environment [15]. However, due to the complex interaction of the antennas with the medium, this function depends on the medium to which the signal goes. Therefore, existing georadars do not provide this kind of 
information before the soundings. In this paper it is proposed to determine the source function on the basis of test experiments conducted on a homogeneous medium.

We formulate a simplified mathematical model of GPR in the wave approximation [28, 29]. As it is common in geophysics, assume that the medium fills the half-space $z>0$ and the half-space $z<0$ corresponds to the air. Let the electrical permittivity $\varepsilon$ of the medium depend on the coordinate $z$ only, magnetic permittivity $\mu=\mu_{0}=$ const $>0$ in the whole space and the conductivity is negligible. Let the current source with intensity

$$
\begin{gathered}
j^{e x}(t)=\Phi(t) \delta(z), \Phi(t)=0, \text { if } t \leq 0, \\
\Phi(t) \in C^{2}[0 . \infty], \Phi^{\prime \prime}(+0) \neq 0
\end{gathered}
$$

be placed at the boundary $z=0$ and directed along the axis $y$. Then it follows from Maxwell's equations [6], that the electromagnetic field depends on $(z, t)$ only. The field has an electric component $E_{2}(z, t)$ along the axis $y$, and a magnetic component $H_{1}(z, t)$ along the axis $x$ that satisfy the Cauchy problem:

$$
\frac{\partial H_{1}}{\partial z}=\varepsilon(z) \frac{\partial E_{2}}{\partial t}+\delta(z) \Phi(t), \frac{\partial E_{2}}{\partial z}=\mu(z) \frac{\partial H_{1}}{\partial t},\left(E_{2}, H_{1}\right)_{t<0}=0 .
$$

We assume below $\mu(z)=\mu_{0}>0$. By taking first derivatives with respect to $t$ from first equation and with respect to $z$ from second one in (1) and eliminating $\partial^{2} H_{1} / \partial t \partial z$ we get:

$$
\partial E^{2} \partial z^{2}=\mu_{0} \varepsilon(z) \frac{\partial E^{2}}{\partial t^{2}}+\mu_{0} \delta(z) \Phi^{\prime}(t), E_{2 \mid t<0}=0 .
$$

Denote by

$$
c(z)=1 / \sqrt{\mu_{0} \varepsilon(z)} .
$$

The purpose of GPR studies is to determine the electrical properties of the medium. Within the framework of our model, we need to recover the specific permittivity function $\varepsilon(z)$. As shown in [15], knowledge of the source function $\Phi(t)$ allows to approximate the function $c(z)$ based on measurements of the field strength on the surface of the medium. Further, according to the $c(z)$ distribution is easy to compute the function $\varepsilon(z)$.

Consider an environment in which the distribution of specific electrical conductivity is subject to the following representation

$$
\begin{gathered}
c^{-2}(z)=\left\{\begin{array}{lll}
c_{0}^{-2}, & \text { if } & z<0 \\
c_{1}^{-2}, & \text { if } & z \geq 0
\end{array}\right. \\
c_{0}, c_{1}=\text { const. }
\end{gathered}
$$

Here $c_{0}$ is the speed of propagation of the signal in the air, and $c_{1}$ - the speed of the radio signal in a homogeneous environment.

$$
\begin{gathered}
E_{z z}=\frac{1}{c^{-2}(z)} E_{z z}+\mu_{0} \Phi(t) \delta(z), \quad(z \in \Re, t>-\infty), \\
\left.E\right|_{t<0} \equiv 0 .
\end{gathered}
$$

In [15] it is shown that in this case the distribution of the electric field in the medium $E_{2}(z, t)=U(z, t)$ is a generalized solution of the Cauchy (2)-(3).

Then the solution of the problem is given by the formula:

$$
E_{z z}(z, t)=-\frac{\mu_{0} c_{0} c_{1}}{c_{0}+c_{1}} \begin{cases}\Phi\left(t+\frac{z}{c_{0}}\right), & z<0 \\ \Phi\left(t-\frac{z}{c_{0}}\right), & z>0\end{cases}
$$

It can be checked directly that the function $E(z, t)$ is continuous anywhere and twice continuously differentiable in the half spaces $\Re_{-}^{2}=\{(z, t) \mid z<0, t \in \Re\}, \Re_{+}^{2}=\{(z, t) \mid z>0, t \in \Re\}$ and its first derivatives at $z=0$ are expressed as

i.e.

$$
E_{z}(-0, t)=-\frac{\mu_{0} c_{1}}{c_{0}+c_{1}} \Phi^{\prime}(t), E_{z}(+0, t)=-\frac{\mu_{0} c_{1}}{c_{0}+c_{1}} \Phi^{\prime}(t),
$$

$$
E_{z}(+0, t)-E_{z}(-0, t)=\mu_{0} \Phi^{\prime}(t) .
$$


The last formula confirms that the second derivative $E_{z z}$ is represented as the singular function $\mu_{0} \Phi^{\prime}(t) \delta(z)$ and a regular one.

From formula (4) it follows that the field strength in the GPR problem of a homogeneous half-space is determined by the formula

$$
g(t)=E(0, t)=-\frac{\mu_{0} c_{0} c_{1}}{c_{0}+c_{1}} \Phi(t),(t>0) .
$$

In GPR studies, readings are taken from the receiving antenna. From formula (5), it follows that the excitation signal generates a field with intensity (5) at the boundary of the medium. This field acts on the receiving antenna, causing alternating current in it. This means that the readings recorded by the device must be proportional to the function $\Phi(t)$.

Thus, before conducting a survey on the object under study, it is necessary to have the data obtained for a homogeneous half-space. This will determine the type of source function and use it for further interpretation. Next, the problem arises with approximation of a smooth function measured on a homogeneous half-space of data. As shown in [15], a second derivative of the function $\Phi(t)$ is needed for further interpretation. Therefore, it is desirable to approximate the table-set measured data with a smooth function of a simple form, for example, the following:

$$
\Phi(t)=A \sin (\omega t+\beta) \exp (-\gamma t)-A \sin \beta .
$$

When data is approximated, it is necessary to select the parameters $\omega, \beta, \gamma$ in function (6).

\section{The results of experimental studies}

As part of the research project under contract No. 132 dated 12.03.2018, experimental studies were conducted in accordance with clause 8 of the calendar plan. To simulate a source of radiation emitted by Loza-V georadar, a site of a sand pit was selected, with a geoelectrical section was previously known. According to GPR data, namely additional information, the inverse problem of source modeling will be subsequently solved. For this purpose, experiments were conducted using different antennas. The expedition was done by Professor of ENU named after L.N. Gumilyov K.T. Iskakov and by senior teacher of KazNPU named after AbayB.B. Sholpanbayev on January 3, 2018. The experiments were conducted on the sandy quarry LLP «Bek», located $30 \mathrm{~km}$ away from the city of Almaty in the direction towards the town of Kapchagai. Radarograms were processed by the 2nd year doctoral candidate D.K. Tokseit The spectral analysis of the radarograms was performed by the senior teacher S.A. Boranbayev Objectives of the study: geophysical examination of the structure of the underlying layers of a homogeneous medium-river sand, modelling of the impulse source from the Loza-V device; determination of the spectral characteristics of signals emitted by antennas: $0.5 \mathrm{~m}, 1 \mathrm{~m}, 1.5 \mathrm{~m}, 3 \mathrm{~m}$; interpretation of a series of radarograms obtained in result of sounding required to solve the inverse problem of source recovery. We present the experimental data: $1.5 \mathrm{~m}$ antenna, 7 tracks, 49 measurements, a step of $0.20-0.2 \mathrm{~m}$ are used. In Figure 1,7 tracks are marked and are denoted as: A0-A6.
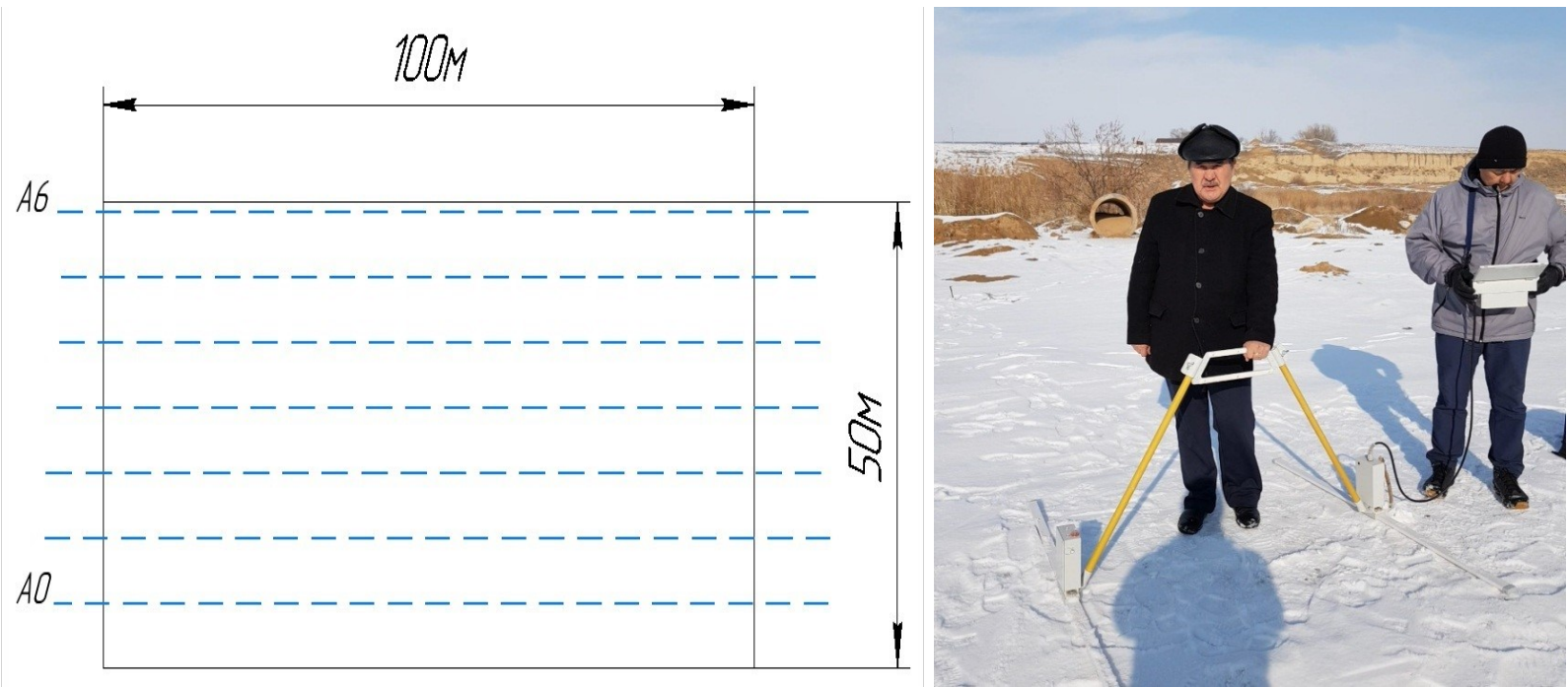

Figure 1. Measurement scheme for experiment № 1 (antenna $1.5 \mathrm{~m}$ ) 
Figure 2 shows the radarogram performed by the program «Krot». The results of the studies with antenna sweep: $1.5 \mathrm{~m}$ antenna, 7 tracks, 49 measurements, step $0.20-0.25 \mathrm{~m}$.

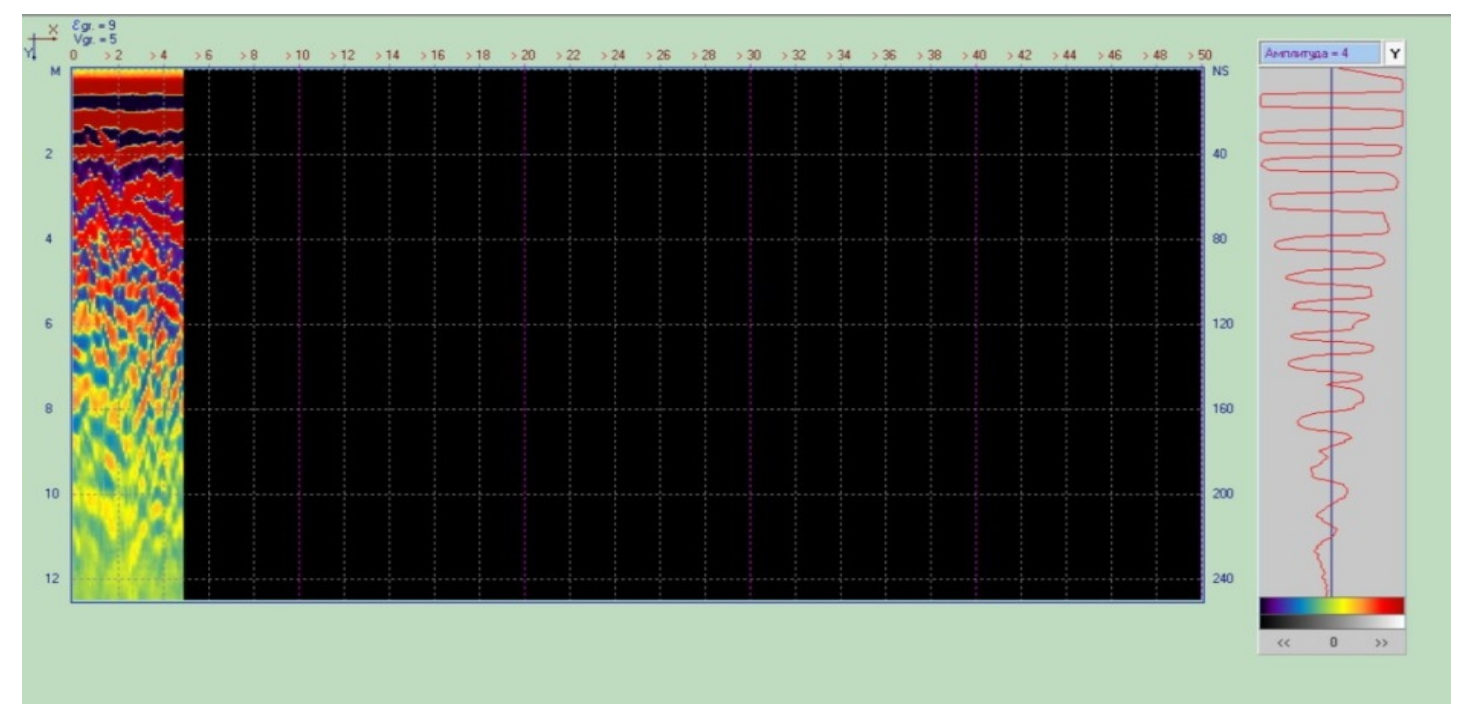

Figure 2. Radarogram of the experiment

4 Radarogram processing - medium response

The graphs of the traces and spectra of the radarograms will be carried out according to the algorithms given in [2]. Figure 3 shows the graphs of the paths and spectrum of radarograms obtained with a $1.5 \mathrm{~m}$ antenna at a frequency of $100 \mathrm{MHz}$.
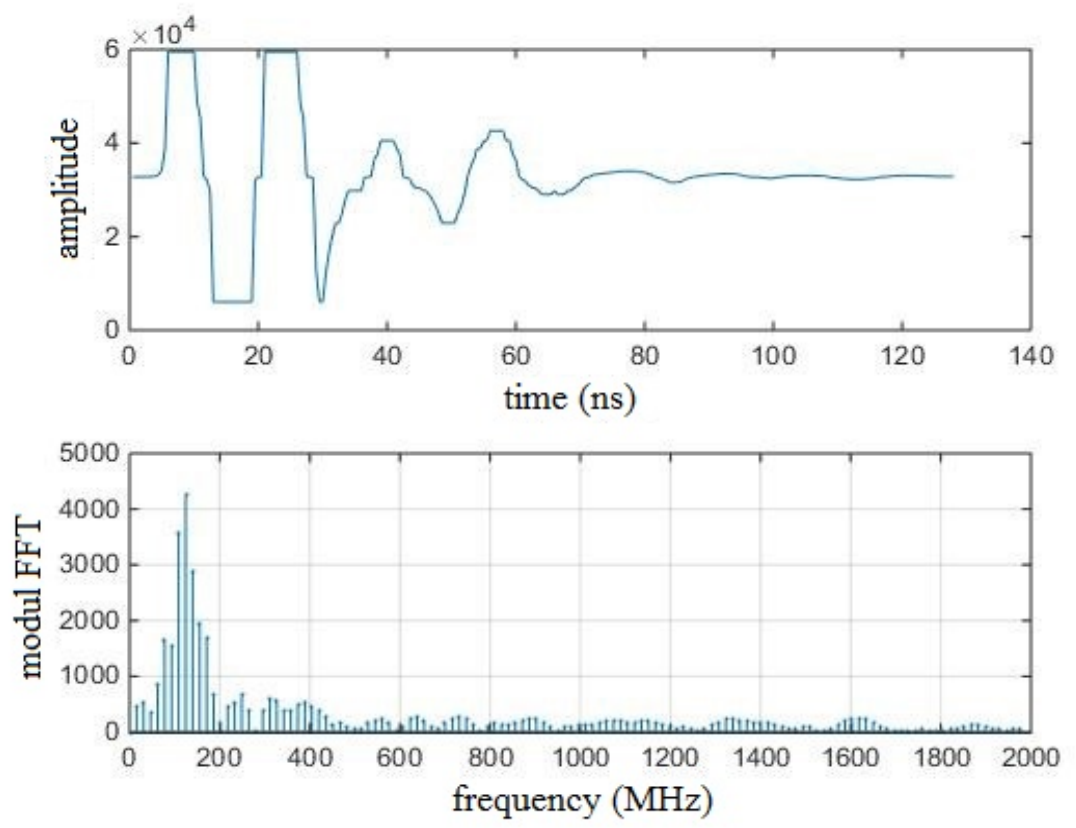

Figure 3. Graphs of the route and spectra of radarograms (1.5 m antenna, $100 \mathrm{MHz})$

Radarogram is an ultra-wideband radio signal. As can be seen from the graphs, the main spectral components of the radarogram, which influence the amplitude of the signal, are located around the center frequency of the GPR antenna. The basic information about the subsurface environment lies in the amplitude of the signal corresponding to the time of receiving the signal. Experimental studies were conducted on the sandy LLP «Bek», 
located $30 \mathrm{~km}$ from Almaty city in the direction towards the city of Kapchagai. Experimental studies were conducted in a sand homogeneous medium at a site of $100 \mathrm{~m}-50 \mathrm{~m}$, using the Loza-V georadar. 147 radarograms on 7 tracks were filmed, in increments of 0.2-0.25 meters using antennas with a sweep of $0.5 \mathrm{~m} ; 1 \mathrm{~m} ; 1.5 \mathrm{~m}$. The length of the profiles in each case is 100 . With antenna $-3 \mathrm{~m}$ received three profiles. Finally, as a confirmation of the calculations, measurements were taken on a hill in which a cut of the medium is visible. Three profiles were received. As a result of the interpretation of the radarograms, a series of responses of the media were obtained, with the use of various antennas, which will be used to solve the inverse problem of source recovery (Table value). A spectral analysis of the received radarograms using the software package was carried out.

5 Numerical results

By the formula (5), we determine

$$
\Phi(t)=g(t) / \kappa, \text { where } \kappa=-\frac{\mu_{0} c_{0} c_{1}}{c_{0}+c_{1}} .
$$

Here $c_{0}$ is the speed of propagation of the signal in the air $c_{0}=0,3 \frac{\mathrm{m}}{\mathrm{ns}}$, and $c_{1}$ - the speed of the radio signal $c_{1}=0,122 \frac{\mathrm{m}}{\mathrm{ns}}-0,15 \frac{\mathrm{m}}{\mathrm{n}}$ in a homogeneous environment in the sand $\mathrm{m} / \mathrm{ns}$, magnetic permittivity in the whole sand $\mu_{0}=1$. Then,

$$
\kappa=-\frac{0,3 \cdot 0,15}{0,45}=-0,1 \frac{\mathrm{m}}{\mathrm{ns}} .
$$

We present the data of the Loza-V GPR, in the form of Table 1. Measurements were carried out with a $1.5 \mathrm{~m}$ antenna, frequency $100 \mathrm{MHz}$. The amplitude values of the signal are ALn1 $=0 \ldots 32768 \ldots 65535$, the amplitudes of the time step are 0.5 ns.).

Table 1

Signal amplitude values

\begin{tabular}{|l|l|l|l|l|l|l|l|l|l|l|l|l|l|}
\hline 32772 & 32772 & 32772 & 32772 & 32772 & 32772 & 32772 & 32772 & 32772 & 32772 & 32772 & 32772 & 32772 & 32772 \\
\hline 32772 & 32772 & 32777 & 32777 & 32777 & 32777 & 32777 & 32777 & 32777 & 32777 & 32777 & 32777 & 32777 & 32777 \\
\hline 32777 & 32777 & 32777 & 32777 & 32783 & 32783 & 32783 & 32783 & 32783 & 32783 & 32783 & 32783 & 32783 & 32783 \\
\hline 32783 & 32783 & 32783 & 32783 & 32783 & 32783 & 32795 & 32795 & 32795 & 32795 & 32795 & 32795 & 32795 & 32795 \\
\hline 32795 & 32795 & 32795 & 32795 & 32795 & 32795 & 32795 & 32795 & 32806 & 32806 & 32806 & 32806 & 32806 & 32806 \\
\hline 32806 & 32806 & 32806 & 32806 & 32806 & 32806 & 32806 & 32806 & 32806 & 32806 & 32829 & 32829 & 32829 & 32829 \\
\hline 32829 & 32829 & 32829 & 32829 & 32829 & 32829 & 32829 & 32829 & 32829 & 32829 & 32829 & 32829 & 32856 & 32856 \\
\hline 32856 & 32856 & 32856 & 32856 & 32856 & 32856 & 32856 & 32856 & 32856 & 32856 & 32856 & 32856 & 32856 & 32856 \\
\hline 32892 & 32892 & 32892 & 32892 & 32892 & 32892 & 32892 & 32892 & 32892 & 32892 & 32892 & 32892 & 32892 & 32892 \\
\hline 32892 & 32892 & 33100 & 33100 & 33100 & 33100 & 33100 & 33100 & 33100 & 33100 & 33100 & 33100 & 33100 & 33100 \\
\hline 33100 & 33100 & 33100 & 33100 & 34248 & 34248 & 34248 & 34248 & 34248 & 34248 & 34248 & 34248 & 34248 & 34248 \\
\hline 34248 & 34248 & 34248 & 34248 & 34248 & 34248 & 38848 & 38848 & 38848 & 38848 & 38848 & 38848 & 38848 & 38848 \\
\hline 38848 & 38848 & 38848 & 38848 & 38848 & 38848 & 38848 & 38848 & 59504 & 59504 & 59504 & 59504 & 59504 & 59504 \\
\hline 59504 & 59504 & 59504 & 59504 & 59504 & 59504 & 59504 & 59504 & 59504 & 59504 & 59504 & 59504 & 59504 & 59504 \\
\hline 59504 & 59504 & 59504 & 59504 & 59504 & 59504 & 59504 & 59504 & 59504 & 59504 & 59504 & 59504 & 59504 & 59504 \\
\hline 59504 & 59504 & 59504 & 59504 & 59504 & 59504 & 59504 & 59504 & 59504 & 59504 & 59504 & 59504 & 59504 & 59504 \\
\hline 59504 & 59504 & 59504 & 59504 & 59504 & 59504 & 59504 & 59504 & 59504 & 59504 & 59504 & 59504 & 59504 & 59504 \\
\hline 59504 & 59504 & 59504 & 59504 & 59504 & 59504 & 59504 & 59504 & 59504 & 59504 & 59504 & 59504 & 59504 & 59504 \\
\hline 59504 & 59504 & 59504 & 59504 & & & & & & & & & & \\
\hline
\end{tabular}

We carry out data normalization in the range from 0 to 1 , with this purpose we will divide all the data in Table 1 by the maximum amplitude value. The data obtained are shown in Table 2 . 
Mathematical modeling of the source...

Table 2

Normalized amplitude values of signals

\begin{tabular}{|c|c|c|c|c|c|c|c|c|c|c|c|c|c|c|}
\hline 0.50 & 0.50 & 0.50 & 0.50 & 0.50 & 0.50 & 0.50 & 0.50 & 0.50 & 0.50 & 0.50 & 0.50 & 0.50 & 0.50 & 0.50 \\
\hline 4185 & 4185 & 4185 & 4185 & 4185 & 4185 & 4185 & 4185 & 4185 & 4185 & 4185 & 4185 & 4185 & 4185 & 4185 \\
\hline 0.50 & 0.50 & 0.50 & 0.50 & 0.50 & 0.50 & 0.50 & 0.50 & 0.50 & 0.50 & 0.50 & 0.50 & 0.50 & 0.50 & 0.50 \\
\hline 4185 & 4262 & 4262 & 4262 & 4262 & 4262 & 4262 & 4262 & 4262 & 4262 & 4262 & 4262 & 4262 & 4262 & 4262 \\
\hline 0.50 & 0.50 & 0.50 & 0.50 & 0.50 & 0.50 & 0.50 & 0.50 & 0.50 & 0.50 & 0.50 & 0.50 & 0.50 & 0.50 & 0.50 \\
\hline 4262 & 4262 & 4354 & 4354 & 4354 & 4354 & 4354 & 4354 & 4354 & 4354 & 4354 & 4354 & 4354 & 4354 & 4354 \\
\hline 0.50 & 0.50 & 0.50 & 0.50 & 0.50 & 0.50 & 0.50 & 0.50 & 0.50 & 0.50 & 0.50 & 0.50 & 0.50 & 0.50 & 0.50 \\
\hline 4354 & 4354 & 4354 & 4538 & 4538 & 4538 & 4538 & 4538 & 4538 & 4538 & 4538 & 4538 & 4538 & 4538 & 4538 \\
\hline 0.50 & 0.50 & 0.50 & 0.50 & 0.50 & 0.50 & 0.50 & 0.50 & 0.50 & 0.50 & 0.50 & 0.50 & 0.50 & 0.50 & 0.50 \\
\hline 4538 & 4538 & 4538 & 4538 & 4708 & 4708 & 4708 & 4708 & 4708 & 4708 & 4708 & 4708 & 4708 & 4708 & 4708 \\
\hline 0.50 & 0.50 & 0.50 & 0.50 & 0.50 & 0.50 & 0.50 & 0.50 & 0.50 & 0.50 & 0.50 & 0.50 & 0.50 & 0.50 & 0.50 \\
\hline 4708 & 4708 & 4708 & 4708 & 4708 & 5062 & 5062 & 5062 & 5062 & 5062 & 5062 & 5062 & 5062 & 5062 & 5062 \\
\hline 0.50 & 0.50 & 0.50 & 0.50 & 0.50 & 0.50 & 0.50 & 0.50 & 0.50 & 0.50 & 0.50 & 0.50 & 0.50 & 0.50 & 0.50 \\
\hline 5062 & 5062 & 5062 & 5062 & 5062 & 5062 & 5477 & 5477 & 5477 & 5477 & 5477 & 5477 & 5477 & 5477 & 5477 \\
\hline 0.50 & 0.50 & 0.50 & 0.50 & 0.50 & 0.50 & 0.50 & 0.50 & 0.50 & 0.50 & 0.50 & 0.50 & 0.50 & 0.50 & 0.50 \\
\hline 5477 & 5477 & 5477 & 5477 & 5477 & 5477 & 5477 & 6031 & 6031 & 6031 & 6031 & 6031 & 6031 & 6031 & 6031 \\
\hline 0.50 & 0.50 & 0.50 & 0.50 & 0.50 & 0.50 & 0.50 & 0.50 & 0.50 & 0.50 & 0.50 & 0.50 & 0.50 & 0.50 & 0.50 \\
\hline 6031 & 6031 & 6031 & 6031 & 6031 & 6031 & 6031 & 6031 & 9231 & 9231 & 9231 & 9231 & 9231 & 9231 & 9231 \\
\hline 0.50 & 0.50 & 0.50 & 0.50 & 0.50 & 0.50 & 0.50 & 0.50 & 0.50 & 0.52 & 0.52 & 0.52 & 0.52 & 0.52 & 0.52 \\
\hline 9231 & 9231 & 9231 & 9231 & 9231 & 9231 & 9231 & 9231 & 9231 & 6892 & 6892 & 6892 & 6892 & 6892 & 6892 \\
\hline 0.52 & 0.52 & 0.52 & 0.52 & 0.52 & 0.52 & 0.52 & 0.52 & 0.52 & 0.52 & 0.59 & 0.59 & 0.59 & 0.59 & 0.59 \\
\hline 6892 & 6892 & 6892 & 6892 & 6892 & 6892 & 6892 & 6892 & 6892 & 6892 & 7662 & 7662 & 7662 & 7662 & 7662 \\
\hline 0.59 & 0.59 & 0.59 & 0.59 & 0.59 & 0.59 & 0.59 & 0.59 & 0.59 & 0.59 & 0.59 & 0.91 & 0.91 & 0.91 & 0.91 \\
\hline 7662 & 7662 & 7662 & 7662 & 7662 & 7662 & 7662 & 7662 & 7662 & 7662 & 7662 & 5446 & 5446 & 5446 & 5446 \\
\hline 0.91 & 0.91 & 0.91 & 0.91 & 0.91 & 0.91 & 0.91 & 0.91 & 0.91 & 0.91 & 0.91 & 0.91 & 0.91 & 0.91 & 0.91 \\
\hline 5446 & 5446 & 5446 & 5446 & 5446 & 5446 & 5446 & 5446 & 5446 & 5446 & 5446 & 5446 & 5446 & 5446 & 5446 \\
\hline 0.91 & 0.91 & 0.91 & 0.91 & 0.91 & 0.91 & 0.91 & 0.91 & 0.91 & 0.91 & 0.91 & 0.91 & 0.91 & 0.91 & 0.91 \\
\hline 5446 & 5446 & 5446 & 5446 & 5446 & 5446 & 5446 & 5446 & 5446 & 5446 & 5446 & 5446 & 5446 & 5446 & 5446 \\
\hline 0.91 & 0.91 & 0.91 & 0.91 & 0.91 & 0.91 & 0.91 & 0.91 & 0.91 & 0.91 & 0.91 & 0.91 & 0.91 & 0.91 & 0.91 \\
\hline 5446 & 5446 & 5446 & 5446 & 5446 & 5446 & 5446 & 5446 & 5446 & 5446 & 5446 & 5446 & 5446 & 5446 & 5446 \\
\hline 0.91 & 0.91 & 0.91 & 0.91 & 0.91 & 0.91 & 0.91 & 0.91 & 0.91 & 0.91 & 0.91 & 0.91 & 0.91 & 0.91 & 0.91 \\
\hline 5446 & 5446 & 5446 & 5446 & 5446 & 5446 & 5446 & 5446 & 5446 & 5446 & 5446 & 5446 & 5446 & 5446 & 5446 \\
\hline 0.91 & & & & 0.91 & & 0.91 & 0.8 & 0.91 & 0.91 & 0.91 & 0.91 & 0.91 & 0.91 & 0.91 \\
\hline 5446 & 5446 & 5446 & 5446 & 5446 & 5446 & 5446 & 5446 & 5446 & 5446 & 5446 & 5446 & 5446 & 5446 & 5446 \\
\hline $\begin{array}{c}0.91 \\
5446\end{array}$ & & & & & & & & & & & & & & \\
\hline
\end{tabular}

Then the environment response schedule:

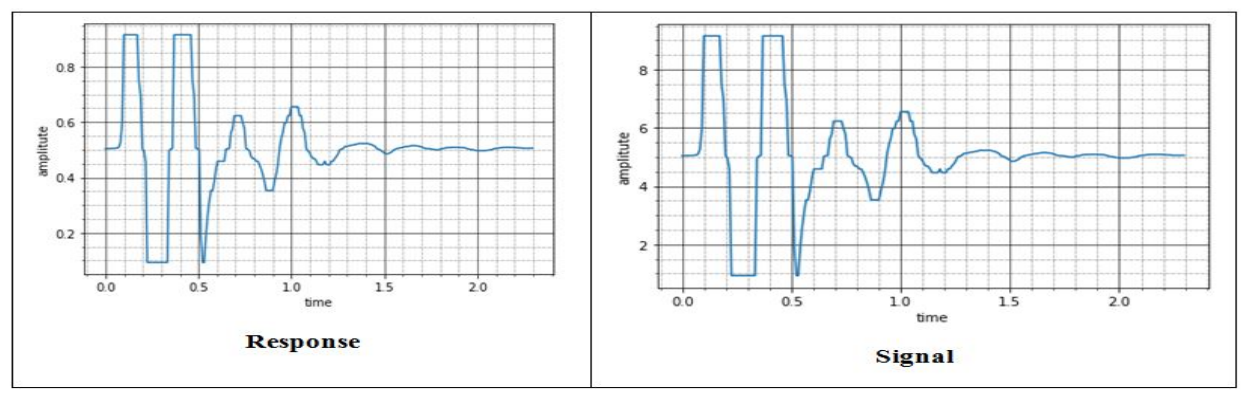

Figure 4. The response of the environment (according to Table 2.).

Disturbance source graph. (Calculated by the formula (5)) 
Below in Figure 5. the signal graph with coefficients minus $\mathrm{k}=-0.1$ is shown.

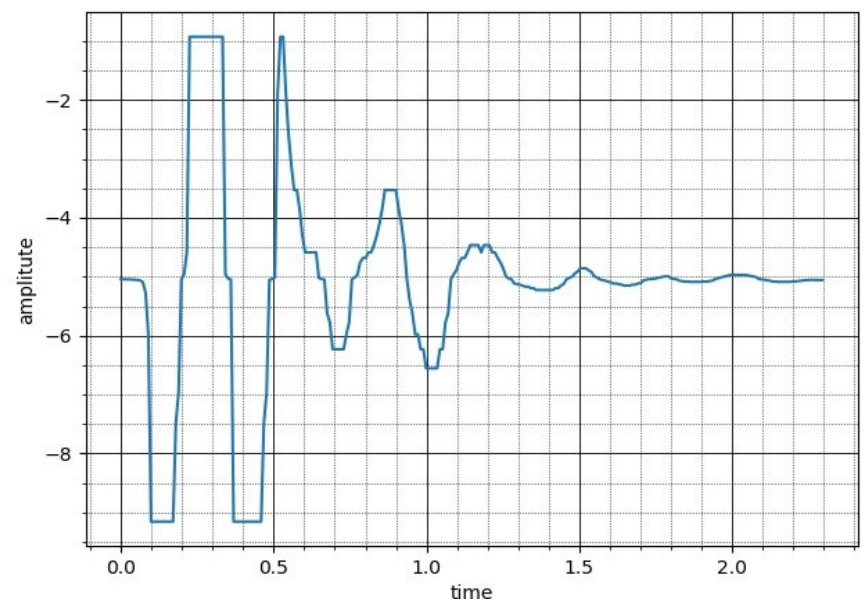

Figure 5. Signal graph with a minus sign

This work was supported by a grant from Ministry of Education and Science of the Republic of Kazakhstan (MES RK) under contract No. 132 dated 12.03.2018 within the framework of the project AP05133922.

\section{References}

1 Bamberger A. About the stability of the inverse problem in 1-D wave equations - applications to the interpretation of seismic profiles / A. Bamberger, G. Chavent, P. Lailly // Applied Mathematic Optimization. - 1979. - 5, 1. - P. 1-47.

2 Bamberger A. Inversion of normal incidence seismograms / A. Bamberger, G. Chavent, Ch. Hemon, P. Lailly // Geophysics. - 1982. - 47, 5 - P. 757-770.

3 Cook D.A. Generalized linear inversion of reflection seismic data / D.A. Cook, W.A. Schneider // Geophysics. - 1983. - 48. - P. 665-676.

4 Johonson W.W. One-dimensional inversion of seismic data / W.W. Johonson, H.H. Nogami // Abstracts of Papers Presented at the 52 Annual International SEG Meeting in Dallas. - Texas, 1982.

5 Chavent G. History matching by use of optimal control theory / G. Chavent, M. Dupuy, P. Lemonnier // Full Meeting of Society of Petroleum Engineers. - Las Vegas. - 1975. — 2. - P. 75-86.

6 Santosa F. Inversion of Band Limited Reflection Seismograms Using Stacking Velocities as Constraints. / F. Santosa, W.W. Symes, G. Raggio // Cornell ONR/SRO Report. - № 29. - Arlington, Virginia. 1985.

7 Romanov V.G. Inverse Problems for Maxwell's Equations / V.G. Romanov, S.I. Kabanikhin. // Utrecht, The Netherlands: VSP. - 1994. - 249 p.

8 Iskakov K.T. The solution of one-dimensional inverse problem of geoelectrics by the method of conjugate gradients / K.T. Iskakov, S.I. Kabanikhin // Journal Theoretical and Applied Mechanics. - 1992. - 2, 3. - P. 197-221.

9 Koptyug I.V. A quantitative NMR imaging study of mass transport in porous solids during drying / I.V. Koptyug, S.I. Kabanikhin, K.T. Iskakov, V.B. Fenelonov, L.Yu. Khitrina, R.Z. Sagdeev, V.N. Parmon // Journal Chemical Engineering Science. - 2000. - 55 - P. 1559-1571.

10 Koptyug I.V. An H NMR microimaging study of water vapor sorption by individual porous pellets / I.V. Koptyug, L.Yu. Khitrina, Yu.I. Aristov, M.M. Tokarev, K.T. Iskakov, V.N. Parmon, R.Z. Sagdeev // Journal of Physical Chemistry. B. - 2000. - 104 - P. 1695-1700.

11 Kabanikhin S.I. Inverse problem for a quasi-linear equation of diffusion / S.I. Kabanikhin, I.V. Koptyug, K.T. Iskakov, R.Z. Sagdeev // Journal of Inverse Ill-Posed Problems. - 1998. - 6, 4 - P. 335-353. 
12 Kabanikhin S.I. Inverse problem for diffusion transport of water upon single pellet moisture sorption / S.I. Kabanikhin, I.V. Koptyug, K.T. Iskakov, R.Z. Sagdeev // International Journal of Nonlinear Sciences and Numerical Simulation. - 2000. - 1, 1 - P. 31-42.

13 Kabanikhin S.I. $\mathrm{H}_{1}$-conditional stability with explicit Lipschitz constant for a one-dimensional inverse acoustic problem / S.I. Kabanikhin, K.T. Iskakov, M. Yamamoto //Journal of Inverse and Ill-Posed Problems. - 2001. - 9, 3. - P. 249-267.

14 Mukanova B. Fourier Collocation Algorithm for identification of a spacewise dependent source in wawe equation from Neumann-type measured data [Electronic resouce] / B. Mukanova, A. Hasanov // Applied Numerical Mathematics. - 2017. - 111. - P. 49-63. - Access mode: http://www.sciencedirect.com/ science/article/pii/S0168927416301738

15 Mukanova B.G. Inverse source problem for wave equation and GPR data interpretation problem / B.G. Mukanova, V.G. Romanov // Eurasian Journal of Mathematical and Computer Applications. 2016. - 4, 3 - P. 15-28.

16 Iskakov K.T. Experimental data of research using ground-penetrating radar «Zond-12c» and interpretation Georadarograms [Electronic resouce]. / K.T. Iskakov, S. Boranbayev, Z. Alimbayeva, B. Isin // Acta physica polonica a. - 2016. - 130. - P. 322-324. - Access mode: http://przyrbwn. icm. edu. pl/APP/PDF /130/a130z1p087.pdf

17 Iskakov K.T. Wavelet processing and filtering of the radargram trace / K.T. Iskakov, S.A. Boranbaev, N. Uzakkyzy // Eurasian Journal of Mathematical and Computer Applications. — 2017. - 5, No. 4. P. 43-54.

18 Oralbekova Zh.O. Existence of the residual functional derivative with respect to a coordinate of gap point of medium [Electronic resouce]. / Zh.O. Oralbekova, K.T. Iskakov, A.L. Karchevsky // Applied and Computational Mathematics. - 2013. - 12, 2. - P. 222-233. - Access mode: http://www.acmij. az/view.php? lang $=$ az\&menu $=$ journal\&id $=323$.

19 Karchevsky A.L. Solution of the inverse problem of subsurface electric exploration for horizontally stratified medium. / A.L. Karchevsky, Zh.O. Oralbekova, K.T. Iskakov // International Journal of Applied Mathematics. - 2013. - No. 432121. - P.1-9.

20 Iskakov K.T., Oralbekova Zh.O. Resolving Power of Algorithm for Solving the Coefficient Inverse Problem for the Geoelectric Equation Mathematical Problems in Engineering. - 2014. - No. 545689. - P. 1-9. DOI: $10.1155 / 2014 / 545689$

21 Karchevsky A.L. Reconstruction of pressure velocities and boundaries of thin layers in thinly-stratified layers / A.L. Karchevsky // Journal of Inverse and Ill-Posed Problems. - 2010. - Vol. 18. - P. 371-388.

22 Marquardt D.W. An algorithm for least-squares estimation of nonlinear parameters / D.W. Marquardt // Journals SIAM. - 1963. - 11. - P. 431-441.

23 Chen Y.M., Seinfeld J.H. Estimation of spatially varying parameters in partial differential equations / Y.M. Chen., J. H. Seinfeld // International Journal of Control. - 1972. - 15, 3 - P. 487-495.

24 Stoyan G. Numerical experiments on the identification of heat conduction coefficients / G. Stoyan. Theory of Nonlinear Operators Proc.Fifth Intern. Summer School, Berlin, 1977). - Berlin: Akademie-Verlag, 1978. - P. 259-268.

25 Ursin B. Comparison of some inverse methods for wave propagation in layered media / B. Ursin, K.A. Berteussen // Proceedings of the IEEE. - 1986. - 74, 3 - Р. 7-19.

26 Финкельштейн М.И. Основы радиолокации: учебник для вузов / М.И. Финкельштейн. - 2-е изд., перераб. и доп. - М.: Радио и связь, 1983.- 536 с.

27 Владов М.Л. Введение в георадиолокацию: учеб. пос. / М.Л. Владов, А.В. Старовойтов. - М.: Изд-во МГУ, 2004. - 153 с.

28 Александров П.Н. Теоретические основы георадарного метода / П.Н. Александров. - М.: Физматлит., 2017. - 112 с.

29 Светов Б.С. Основы геоэлектрики / Б.С. Светов. - М.: Наука, 2008. - 656 с. 
Қ.Т. Искаков, Б.Г. Мұқанова, А.С. Бердышев, А.С. Кембай, Д.Қ. Тоқсеит

\title{
Геоэлектрика теңдеуі үшін негіздің және орта реакциясын математикалық модельдеу
}

\begin{abstract}
Мақалада GPR құралы шығаратын электрмагниттік толқындардың қозғалыс негізі уақыт функциясы ретінде анықтау үшін алгоритм ұсынылған. Бұл мәселені шешуге арналған математикалық модель модельдік деректер бойынша құрастырылып, сыналды. Нақты георадар деректеріне негізделген бастапқы функция құру үшін алгоритм таңдалды. Осы мақсатта Лоза-В георадарын қолданып, бұл салада жүргізілген эксперименттік зерттеулердің нәтижелері пайдаланылды. «Ауа - құм» ортаға эксперимент жүргізілді. Ортадан алынған дабыл кедергі және шудан тазартылған. Бұл үшін біз радиолокацияларды өңдеу үшін жиілік сүзгісін, сигналдың орташалануын, амплитудалық түзетуді қолданылды. Болашақта біркелкі емес медианы зерттеуге, соның ішінде оқшауланған нысандарды анықтауға алынған бұзылулардың кестелік толқындық формасы пайдаланылды. Қарастырылған мәселелер бойынша есептер сериясы келтірілген.
\end{abstract}

Kiлm сөздер: кері есептер, көздерді модельдеу, Максвелл теңдеуі, жиілікті сүзу, радиограмманы өңдеу, сандық нәтижелер.

К.Т. Искаков, Б.Г. Муканова, А.С. Бердышев, А.С. Кембай, Д.К. Токсеит

\section{Математическое моделирование источника и отклика среды для уравнения геоэлектрики}

В статье предложен алгоритм определения источника возбуждения электромагнитных волн, излучаемых георадиолокационным прибором, как функции времени. Математическая модель для решения этой задачи построена и апробирована на модельных данных. Авторами построен алгоритм по построению функции источника на основе реальных данных георадара. В этих целях использованы результаты экспериментальных исследований, проведенных в полевых условиях с применением георадара Лоза-В. Проведены эксперименты в среде «воздух - песок». Полученный сигнал отклика среды обработан от помех и шумов. Для обработки радарограмм использованы частотная фильтрация, усреднение сигналов, коррекция амплитуд. В дальнейшем полученная табличная форма сигнала возмущения будет использована для исследования неоднородных сред, в том числе и для изучения локализованных объектов. Приведены серии расчетов для рассматриваемых задач.

Ключевые слова: обратные задачи, моделирование источников, уравнение Максвелла, частотная фильтрация, обработка радарограммы, численные результаты.

\section{References}

1 Bamberger, A., Chavent, G. \& Lailly, P. (1979). About the stability of the inverse problem in 1-D wave equations - applications to the interpretation of seismic profiles. Applied Mathematic Optimization, 5, 1, $1-47$.

2 Bamberger, A., Chavent, G., Hemon, Ch. \& Lailly, P. (1982). Inversion of normal incidence seismograms. Geophysics, 47, 5, 757-770.

3 Cook, D.A. \& Schneider, W.A. (1983). Generalized linear inversion of reflection seismic data. Geophysics, 48, 665-676.

4 Johonson, W.W. \& Nogami, H.H. (1982). One-dimensional inversion of seismic data. Abstracts of Papers Presented at the 52 Annual International SEG Meeting in Dallas, Texas.

5 Chavent, G., Dupuy, M. \& Lemonnier, P.(1975). History matching by use of optimal control theory. Full Meeting of Society of Petroleum Engineers. Las-Vegas, 2, 75-86.

6 Santosa, F., Symes, W.W. \& Raggio, G.(1985). Inversion of Band Limited Reflection Seismograms Using Stacking Velocities as Constraints. Cornell ONR/SRO Report, Arlington, Virginia. 
7 Romanov,V.G. \& Kabanikhin, S.I. (1994). Inverse Problems for Maxwell's Equations. Utrecht, The Netherlands: VSP, 249 p.

8 Iskakov, K.T. \& Kabanikhin, S.I. (1992). The solution of one-dimensional inverse problem of geoelectrics by the method of conjugate gradients. Journal Theoretical and Applied Mechanics, 2, 3, $197-221$.

9 Koptyug, I.V., Kabanikhin, S.I., Iskakov, K.T., Fenelonov, V.B., Khitrina, L.Yu., Sagdeev, R.Z. \& Parmon, V.N. (2000). A quantitative NMR imaging study of mass transport in porous solids during drying. Journal Chemical Engineering Science, 55, 1559-1571.

10 Koptyug, I.V., Khitrina, L.Yu., Aristov, Yu.I., Tokarev, M.M., Iskakov, K.T., Parmon, V.N., \& Sagdeev, R.Z. (2000). An H NMR microimaging study of water vapor sorption by individual porous pellets. Journal of Physical Chemistry B., Vol 104, 1695-1700.

11 Kabanikhin, S.I., Koptyug, I.V., Iskakov, K.T. \& Sagdeev, R.Z. (1998). Inverse problem for a quasi-linear equation of diffusion. Journal of Inverse Ill-Posed Problems, 6, 4, 335-353.

12 Kabanikhin, S.I., Koptyug, I.V., Iskakov, K.T., \& Sagdeev, R.Z. (2000). Inverse problem for diffusion transport of water upon single pellet moisture sorption. International Journal of Nonlinear Sciences and Numerical Simulation, Vol 1, 1, 31-42.

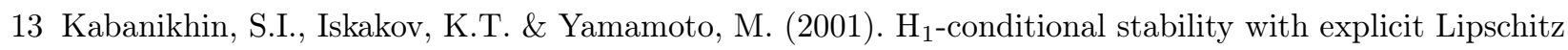
constant for a one-dimensional inverse acoustic problem. Journal of Inverse and Ill-Posed Problems, 9, №3, 249-267.

14 Mukanova, B.G., \& Hasanov, A. (2017). Fourier Collocation Algorithm for identification of a spacewise dependent source in wawe equation from Neumann-type measured data. Applied Numerical Mathematics, 111, 49-63. Retrieved from http://www.sciencedirect.com/science/article/ pii/S0168927416301738.

15 Mukanova, B.G., \& Romanov, V.G. (2016). Inverse source problem for wave equation and GPR data interpretation problem. Eurasian Journal of Mathematical and Computer Applications, 4, 3, 15-28.

16 Iskakov, K.T., Boranbayev, S.A., Alimbayeva, Z., \& Isin, B. (2016). Experimental data of research using ground-penetrating radar «Zond-12c» and interpretation Georadarograms. Acta physica polonica a., 130, 322-324. Retrieved from http://przyrbwn.icm.edu.pl/APP/PDF/130/a130z1 p087.pdf.

17 Iskakov, K.T., Boranbaev, S.A. \& Uzakkyzy, N. (2017). Wavelet processing and filtering of the radargram trace. Eurasian Journal of Mathematical and Computer Applications, 5, 4, 43-54.

18 Oralbekova, Zh.O., Iskakov, K.T., \& Karchevsky, A.L. (2013). Existence of the residual functional derivative with respect to a coordinate of gap point of medium. Applied and Computational Mathematics, 12, 2, 222-233. Retrieved from http://www.acmij.az/view.php? lang=az\&menu= journal\&id=323.

19 Karchevsky, A.L., Oralbekova, Zh.O., \& Iskakov, K.T. (2013). Solution of the inverse problem of subsurface electric exploration for horizontally stratified medium. International Journal of Applied Mathematics, No. 432121, 1-9.

20 Iskakov, K.T., \& Oralbekova, Zh.O. (2014). Resolving Power of Algorithm for Solving the Coefficient. Inverse Problem for the Geoelectric Equation Mathematical Problems in Engineering, No. 545689, 1-9. DOI: $10.1155 / 2014 / 545689$.

21 Karchevsky, A.L. (2010). Reconstruction of pressure velocities and boundaries of thin layers in thinlystratified layers. Journal of Inverse and Ill-Posed Problems, 18, 371-388.

22 Marquardt, D.W. (1963). An algorithm for least-squares estimation of nonlinear parameters. Journals SIAM, 11, 431-441.

23 Chen, Y.M., \& Seinfeld J.H. (1972). Estimation of spatially varying parameters in partial differential equations. International Journal of Control, 15, 3, 487-495.

24 Stoyan, G. (1978). Numerical experiments on the identification of heat conduction coefficients. Theory of Nonlinear Operators. Proc. Fifth Intern. Summer School, Berlin: Akademie-Verlag, 1977, 259-268.

25 B. Ursin, \& Berteussen, K.A. (1986). Comparison of some inverse methods for wave propagation in layered media. Proceedings of the IEEE, Vol 74, 3, 7-19.

26 Finkelshtein, M.I. (1983). Osnovy radiolokatsii: uchebnik dlia vuzov [Fundamentals of radar: the textbook for high schools]. (2nd ed.). Moscow: Radio i sviaz [in Russian].

27 Vladov, M.L (2004). Vvedenie v heoradiolokatsiiu [Introduction to ground penetrating radar]. Moscow: Izdatelstvo MHU [in Russian]. 
28 Aleksandrov, P.N. (2017). Teoreticheskie osnovy heoradarnoho metoda /The theoretical basis of the GPR method]. Moscow: Fizmatlit [in Russian].

29 Svetov, B.S. (2008). Osnovy heoelektriki [Basics of geoelectrics]. Moscow: Nauka [in Russian]. 